\title{
MENELADANI NILAI-NILAI KARAKTER KOMUNITAS MAHASANTRI (STUDI PONDOK PESANTREN ASSHODIQIYAH SEMARANG)
}

\author{
Moh. Farhan \\ moh.farhan@unissula.ac.id
}

\begin{abstract}
This article would like to examine the values of the characters of students Asshodiqiyah islamic Boarding School Semarang. Character education is a very strategic issue today. This can be seen from the many cases of moral decadence that has entered the world of education. Starting from the persecution of students even to murder. Of course this causes anxiety for all of us.

From that, it is necessary to be disclosed as one prototype model of character value education conducted in islamic boarding school as an indigenous institution that has proven to be the front guard in carrying out character education because the students of this islamic boarding school live for 24 hours under the watch of the kiai.

The issues raised in this article are: 1) How is the activity of the students in Asshodiqiyah islamic boarding school Semarang, 2) What are the character values developed in Asshodiqiyah islamic boarding school Semarang. This research is a qualitative descriptive research in which the researcher presents various data obtained from observation, interview, and documentation.

From the research that has been done, the results show that: 1) students' activity in Asshodiqiyah islamic boarding school Semarang can be classified in the form of routine and incidental activity, whereas 2) The character values developed in Asshodiqiyah islamic boarding school Semarang are religious, honest, discipline, hard work, creative, independent, democratic, curiosity, spirit of nationalism, love of the homeland, appreciate achievement, communicative, love peace, love reading, caring environment, social care, responsibility.
\end{abstract}

Keywords: Values, characters, Asshodiqiyah islamic boarding school.

\begin{abstract}
Abstrak
Artikel ini ingin mengkaji tentang Nilai-nilai karakter dalam komunitas mahasantri di Pondok Pesantren Asshodiqiyah Semarang. Pendidikan karakter menjadi isu yang sangat
\end{abstract}


strategis dewasa ini. Hal tersebut bisa kita lihat dari banyaknya kasus dekadensi moral yang sudah masuk dalam dunia pendidikan. Mulai dari penganiayaan yang dilakukan siswa bahkan sampai pembunuhan. Tentu saja hal ini menyebabkan kegelisahan bagi kita semua.

Dari itulah perlu kiranya untuk diungkap sebagai salah satu prototype model pendidikan nilai karakter yang dilakukan di pesantren sebagai lembaga indigenous yang telah terbukti menjadi garda terdepan dalam melaksanakan pendidikan karakter karena memang para santri bermukim selama 24 jam di bawah pantauan sang kiai.

Permasalahan yang diangkat dalam artikel ini adalah : 1) Bagaimana aktifitas mahasantri di Pondok Pesantren Asshodiqiyah Semarang, 2) Apakah nilai-nilai karakter yang dikembangkan di Pondok Pesantren Asshodiqiyah Semarang. Penelitian ini merupakan penelitian deskriptif kualitatif yang mana peneliti menyajikan berbagai macam data yang diperoleh dari hasil observasi, wawancara, dan dokumentasi.

Dari penelitian yang telah dilakukan, didapatkan hasil bahwa: 1) Aktifitas mahasantri di Pondok Pesantren Asshodiqiyah Semarang dapat diklasifikasikan berupa kegiatan rutin dan insidental, sedangkan 2) Nilai-nilai karakter yang dikembangkan di Pondok Pesantren Asshodiqiyah Semarang diantaranya berupa nilai religius, jujur, toleransi, disiplin, kerja keras, kreatif, mandiri, demokratis, rasa ingin tahu, semangat kebangsaan atau nasionalisme, cinta tanah air, menghargai prestasi, komunikatif, cinta damai, gemar membaca, peduli lingkungan, peduli sosial, tanggung jawab.

Keywords: Nilai, karakter, pesantren Asshodiqiyah

\section{A. Pendahuluan}

Pendidikan karakter menjadi isu strategis untuk dibincangkan di Indonesia. Hal tersebut dapat dipahami karena memang pendidikan karakter merupakan salah satu isu sentral bangsa Indonesia. Maka tidak heran jika pemerintah sempat menetapkan kebijakan pembangunan karakter bangsa tahun 2010-2025 melalui berbagai langkah strategis, diantaranya penyusunan Desain Induk Pendidikan Karakter pada tahun 2010 yang lalu ${ }^{1}$.

Tampaknya isu terkait dengan pendidikan karakter ini terus saja menggelinding ke permukaan karena memang menjadi suatu kepentingan yang sangat mendesak untuk segera di atasi atas berbagai macam problematika yang merongrong pendidikan karakter tersebut. Pantas saja berbagai elemen bahu membahu mendukung terealisasinya internalisasi pendidikan karakter khususnya dalam bidang pendidikan.

Begitu pentingnya pendidikan untuk menanamkan nilai-nilai karakter mulia kepada peserta didik, tampaknya saat ini malah terjadi kondisi yang bertolak belakang. Betapa akhirakhir ini publik dibuat tercengang dengan munculnya berbagai kasus dekadensi moral yang menyerang generasi bangsa. Bahkan hal tersebut terjadi dalam institusi suci berupa lembaga pendidikan. Seperti kasus meninggalnya seorang guru bernama Ahmad Budi Cahyono di

1 Haedar Nashir, Pendidikan Karakter Berbasis Agama \& Budaya, (Yogyakarta: Multi Presindo, 2013), hal. ix. 
Kabupaten Sampang, akibat dianiaya olseh muridnya sendiri (www. http://nasional.kompas. com). Bahkan terjadi berbagai macam kasus amoral seperti tawuran antar pelajar, tampaknya menambah sederek rapot merah bagi dunia pendidikan.

Sebagaimana ditergaskan oleh Presiden Joko Widodo dalam sambutannya saat membuka acara Rembuk Nasional Pendidikan dan Kebudayaan tahun 2018 di Depok Jawa Barat, menyatakan bahwa berbagai problem yang menjangkit pendidikan dewasa ini mengharuskan bahwa pendidikan yang dilaksanakan di sekolah hendaknya tidak boleh hanya terfokus pada peningkatan kecerdasan intelektual, namun wajib ditekankan juga pada pendidikan nilai karakter $^{2}$. Dari pernyataan tersebut terlihat betapa sangat pentingnya penanaman pendidikan nilai karakter pada peserta didik.

Melihat kondisi tersebut tampaknya diperlukan strategi khusus dalam rangka untuk menanamkan nilai-nilai karakter pada peserta didik, salah satunya dengan berkaca kepada langkah strategis yang sudah diterapkan oleh pesantren. Apalagi akhir-akhir ini muncul fenomena pesantren mahasiswa, yaitu pesantren yang notabennya santrinya merupakan mahasiswa, yang bisanya kemudian disebut dengan "mahasantri". Salah satu pesantren dengan santri berstatus mahasiswa adalah Pondok pesantren Asshodiqiyah yang berada di wilayah Semarang. Dimana pesantren ini merupakan salah satu lembaga pendidikan yang menjadi garda terdepan dalam rangka membangun karakter peserta didiknya.

Oleh sebab itulah dalam artikel ini akan dipaparkan terkait dengan keteladan nilai-nilai karakter komunitas mahasantri di Pondok Pesantren Ash-Shodiqiyyah Semarang. Harapannya supaya bisa menjadi pegangan bagi lembaga pendidikan lain dalam rangka mewujudkan masyarakat yang berkarakter.

\section{B. Metodologi Penelitian}

Penelitian ini menggunakan deskriptif kualitatif. Fokus penelitian merupakan aktifitas mahasiswa santri di Pondok Pesantren Asshodiqiyah Semarang. Pengumpulan data menggunakan teknik wawancara, observasi dan juga dokumentasi.

\section{Nilai-Nilai Karakter}

\section{Definisi Nilai Karakter}

Pembangunan nilai karakter bangsa sangat penting untuk dilaksanakan, karena bertujuan untuk membina dan mengembangkan karakter warga negara sehingga mampu mewujudkan masyarakat yang berkehidupan sesuai dengan nilai-nilai Pancasila.

Secara bahasa, karakter diartikan sebagai sifat-sifat kejiwaan, akhlak ataupun budi pekerti yang bisa membedakan antara satu orang dengan lainnya, bisa juga disebut tabiat atau watak ${ }^{3}$. Karakter ini berasal dari bahasa Inggris (character) mengukir corak yang tetap dan juga tidak dapat terhapus, sehingga dalam makna terminologi sering diidentikan dengan perpaduan dari segala

2 www.http://nasional.kompas.com, diakses 19 Februari 2018, pukul 21.45 wib.

3 Departemen Pendidikan dan Kebudayaan, Kamus Besar Bahasa Indonesia, (Jakarta: Balai Pustaka, 1997), cet. 9, hal. 444 . 
macam tabiat manusia yang sifatnya cenderung tetap sehingga menjadi ciri khas dan pembeda antara satu orang dengan selainnya ${ }^{4}$. Sedangkan menurut Kemendiknas mendefinisikan bahwa karakter adalah watak, tabiat, akhlak, ataupun kepribadian dari seseorang yang terbentuk dari hasil internalisasi dari berbagai kebaikan yang diyakini seseorang yang dipergunakan sebagai cara pandang, bersikap, dan juga bertindak.

\section{Macam-macam}

Menurut Kemendiknas Indonesia, nilai-nilai karakter yang dikembangkan dalam pendidikan harus mencakup nilai moral, agama, dan kebudayaan. Nilai-nilai tersebut berupa 18 poin pendidikan karakter, yaitu sebagai berikut: 1) Religius. 2) Jujur. 3) Toleransi. 4) Disiplin. 5) Kerja keras. 6) Kreatif. 7) Mandiri. 8) Demokratis. 9) Rasa ingin tahu. 10) Semangat kebangsaan atau nasionalisme. 11) Cinta tanah air. 12) Menghargai prestasi. 13) Komunikatif. 14) Cinta damai. 15) Gemar membaca. 16) Peduli lingkungan. 17) Peduli sosial, dan 18) Tanggung jawab.

Sedangkan dalam buku Character Building: Menuju Indonesia Lebih Baik, disampaikan bahwa karakter dapat dibedakan atas dua hal, yaitu karakter pokok dan karakter pilihan. Karakter pokok menjadi asas bagi karakter pilihan. Adapun yang termasuk karakter pokok meliputi karakter dasar, karakter unggul dan kakarter pemimpin. Sedangkan karakter dasar terdiri atas tiga sifat utama yaitu tidak egois, jujur, dan disiplin. Karakter unggul terdiri atas tujuh sifat baik yaitu ikhlas, sabat, bersyukur, bertanggung jawab, berkorban, memperbaiki diri, dan juga bersungguhsungguhal. Karakter pemimpin meliputi Sembilan sufat yaitu adil, arif, bijaksana, kesatria, tawadhu, sederhana, visioner, solutif, komunikatif, dan juga inspiratif. Sedangkan karakter pilihan merupakan perilaku baik yang melekat pada profesi pekerjaan masing-masing orang ${ }^{5}$.

\section{Potret Pesantren Asshodiqiyah}

\section{Sejarah}

Pesantren Asshodiqiyah dibuka sekitar tahun 2011. Pesantren ini merupakan bagian dari yayasan Asshodiqiyahal. Sebuah yayasan yang bergerak di bidang sosial keagamaan dan manajemen, pendidikan, penelitian, dakwah, bimbingan haji dan umrah serta kegiatan-kegiatan lain yang tidak bertentangan dengan agama dan pembangunan sosial. Yayasan Asshodiqiyah didirikan dengan Akte Notaris Nomor 10 tanggal 14 September 1998 diketuai oleh seorang Kyai yang kharismatik yaitu KHal. Shodiq Hamzah yang selama ini dikenal melaksanakan Bimbingan Haji KBIH (Kelompok Bimbingan Ibadah Haji) dan Umroh dengan jama’ah sekitar 500 orang setiap musim haji.

Yayasan Asshodiqiyyah terletak diatas tanah Hak Milik seluas kurang lebih 2,9 Ha. Di atas tanah ini telah berdiri sebuah Masjid (Al Mabrur), Pondok Pesantren Putra dan Putri, Gedung SMK, Gedung SMP IT, dan Gedung yang sedang dibangun akan diperuntukkan Aula, BMT dan KOPONTREN.

4 Ki Hadjar Dewantara, Menuju Manusia Merdeka, (Yogyakarta: Leutika, 2009), hal. 87.

5 Erie Sudewo, Character Building: Menuju Indonesia Lebih Baik, (Jakarta: Repulbika Penerbit, 2011, hlm, $15-16$. 
Tanah yang luas dengan bangunan ini dahulu adalah rawa-rawa yang rata-rata berkedalaman 3 meter. Rawa ini digunakan oleh para penduduk setempat untuk memancing. Namun karena rawa ini dikuasai oleh preman, sehingga yang hendak memancing ditarik biaya 10-15 ribu. Puncaknya adalah konflik ketika proses pengebrukan, truk-truk pada awal pembangunan pondok banyak diberhentikan oleh preman-preman dan hal ini menimbulkan kemarahan dari Kyai Shodiq. Kemudian beliau menemui pimpinan preman-preman yang menghambat pembangunan itu, singkat cerita ketua preman itu akhirnya dengan legowo mempersilahkan proyek tersebut berjalan. Juga terjadi hal-hal berbau mistis, suatu ketika KHal. Shodiq Hamzah menemui salah satu gurunya untuk meminta bantuan karena selama proses pembangunan beberapa keganjilan terjadi, seperti seringnya tukang bangunannya terjatuh hingga dirawat di Rumah Sakit.

Bagunan yang dibangun adalah rumah pribadi KHal. Shodiq Hamzah, masjid dan bangunan pondok (yang saat ini menjadi pondok putri). Demikianlah sejarah singkat berdirinya pondok pesantren Asshodiqiyah yang penuh dengan cerita menarik. ${ }^{6}$

\section{Letak Geografis}

Asshodiqiyah yang beralamatkan di Kelurahan Sawah Besar nomor 10 RT. 05 RW. 01 Kaligawe Semarang termasuk dalam kecamatan Gayamsari kota Semarang, terletak $5 \mathrm{~m}$ di atas permukaan laut dengan suhu maksimum dan minimum berkisar antara $45^{\circ} \mathrm{C}-32^{\circ} \mathrm{C}$ dengan dataran rendahal. Adapun batas-batas wilayah kelurahan Sawah Besar sebagai berikut:

a. Sebelah utara kelurahan Kaligawe

b. Sebelah selatan kelurahan Sambirejo

c. Sebelah barat kelurahan Mlatiharjo

d. Sebelah timur kelurahan Muktiharjo

3. Keunikan

Pesantren As Shodiqiyah berlokasi di pinggir rel kereta api dan dahulunya dikelilingi rawarawa. Uniknya walaupun masih relatif baru, jumlah santrinya sudah mencapai seratus lebih yang sebagian besar adalah mahasiswa.

\section{E. Aktifitas Mahasantri Pesantren Asshodiqiyah}

Secara umum, aktifitas para santri di lingkungan Pesantren Asshodiqiyah dapat diklasifikasikan dalam 2 hal yaitu sebagai berikut:

\section{Rutin}

Sebagaimana umumnya kegiatan rutin di Pondok Pesantren, disini ada rutinitas berupa mengaji setelah Shubuh, Ashar dan Isya'. Hari minggu kerja bakti/roan disekitar pondok. Bakda maghrib ada kegiatan berupa tadarus al-Qur'an. Setiap malam minggu setoran hafalan. Malam jum'at ada kegiatan yasinan dan tahlil serta dzibaan. Malam rabu kegiatan belajar Bahasa inggris. 


\section{Insidental}

Aktifitas insidental diantaranya Gerakan santri menulis, Kegiatan-kegiatan NU, ziarah, Qurban, haflah Akhirussanah dan bahtsul masail.

\section{F. Keteladanan Nilai Karakter Mahasantri Asshodiqiyah}

\section{Religius}

Religius menurut KBBI berarti bersifat religi; bersifat keagamaan; yg bersangkut-paut dengan agama.

Kegiatan bernafaskan religiusitas tercermin dalam segala kegiatan santri, mulai dari bangun tidur hingga tidur kembali, seperti ngaji, sholat jamaah, diniyah, wisata religi ke makam para wali dan lain sebagainya. Bahkan dalam hal memberi hukuman untuk santri yang mbalelo yaitu santri yang tidak mengikuti kegiatan pesantren juga bersifat religius, seperti membaca Yasin dan Surat Al Kahfi. Sedangkan takzir bagi santri yang terlambat kembali dari rumah membaca tahlil ${ }^{7}$. Semua itu pada akhirnya menciptakan atmosfer yang menentramkan hati, membentuk jiwa-jiwa yang unggul dalam hal kerohanian dan taat beragama. Ini berkaitan pula dengan kebutuhan penting manusia yaitu religiusitas atau spiritualitas. Spiritualitas adalah keyakinan dalam hubungannya dengan Yang Maha Kuasa dan Maha Pencipta, sebagai contoh seseorang yang percaya kepada Allah sebagai Pencipta atau sebagai Maha Kuasa. Spiritualitas mengandung pengertian hubungan manusia dengan Tuhannya dengan menggunakan instrumen (medium) sholat, puasa, zakat, haji, doa dan sebagainya. ${ }^{8}$

\section{Jujur}

Menurut KBBI, jujur berarti dapat dipercaya, tidak bohong, lurus hati, berkata apa adanya, tidak curang, tulus, dan ikhlas. Sikap jujur yang dimiliki para santri terlihat pada kehidupannya yang sederhana dan tidak memiliki ambisi yang tinggi tentang kenikmatan duniawi. Oleh para santri kenikmatan duniawi yang berlebihan dianggap sebagai hubbuddunya (cinta dunia).

Bagi santri, kejujuran adalah harga mahal yang menjadi modal diri dalam menempa kehidupan yang berisi ujian dan cobaan. Mengatakan kebenaran walau pahit jelas menjadi pegangan dalam menjunjung tinggi nilai-nilai kejujuran ${ }^{9}$. Mereka meyakini peringatan Allah sebagaimana arti dari ayat al-Qur'an:

"Hai orang-orang yang beriman, bertaqwalah kamu kepada Allah dan katakanlah perkataan yang benar, niscaya Allah memperbaiki bagimu amal-amalmu dan mengampuni bagimu dosa-dosamu. Dan barangsiapa mentaati Allah dan Rasul-Nya, maka sesungguhnya ia telah mendapat kemenangan yang besar". (Q.S.Al-Ahzab: 70-71).

\section{Toleransi}

Toleransi berasal dari bahasa latin "tolerantia" yang berarti kelonggaran, kelembutan hati,

7 Hasil wawancara dengan pengurus pesantren putri, jam 21.30 WIB, 22 Februari 2018

8 Hamid, A. Y, Bunga Rampai Asuhan Keperawatan Jiwa. (Jakarta: Penerbit Buku Kedokteran EGC, 2009), hal. 59

9 Hasil wawancara dengan santri pesantren putra, jam 22.10 WIB, Jumat, 23 Februari 2018 
keringanan dan kesabaran. Toleransi, menurut Kemendiknas berarti sikap dan perilaku yang mencerminkan penghargaan terhadap perbedaan agama, aliran kepercayaan, suku, adat, bahasa, ras, etnis, pendapat, dan hal-hal lain yang berbeda dengan dirinya secara sadar dan terbuka, serta dapat hidup tenang di tengah perbedaan tersebut.

Kondisi santri yang ada di Pesantren Asshodiqiyah tidak ada sekat yang membedakan mereka. Walaupun berbeda fakultas atau program studi, namun mereka dibiasakan untuk bersikap saling rukun dan memahami antara satu dengan lainnya. Di pondok pesantren ditanamkan nilai-nilai persaudaraan, dalam satu kamar terdiri atas 5 s.d 10 santri dengan berbagai karakter dan asal daerahal. Harapannya supaya bisa terjalin persaudaraan baik selama di pesantren maupun diluar pesantren. Tidak jarang kita lihat tingkat kesetia-kawanan antara santri itu tercermin dengan adanya nasab dari satu kyai ketika mereka lulus dan mendirikan pondok pesantren di daerahnya masing-masing. Keakraban yang tampak meski sudah puluhan tahun berpisah setelah meraka lulus dari Pondok Pesantren tempat mereka menimba ilmu.

Sebagaimana yang telah Allah perintahkan dalam surat Al-Hujuraat ayat 13:

"Wahai manusia, sesungguhnya Kami telah menciptakan kalian dalam keadaan sama, dari satu asal: Adam dan Hawâ. Lalu kalian Kami jadikan, dengan keturunan, berbangsa-bangsa dan bersuku-suku, supaya kalian saling mengenal dan saling menolong. Sesungguhnya orang yang paling mulia derajatnya di sisi Allah adalah orang yang paling bertakwa di antara kalian. Allah sungguh Maha Mengetahui segala sesuatu dan Maha Mengenal, yang tiada suatu rahasia pun tersembunyi bagi-Nya".

\section{Disiplin}

Menurut Kemendiknas disiplin merupakan kebiasaan dan tindakan yang konsisten terhadap segala bentuk peraturan atau tata tertib yang berlaku. Keteraturan dan kesadaran dalam melaksanakan segala aktivitas kehidupan.

Pendidikan kedisiplinan yang dilakukan santri tercermin dalam kegiatan ibadahal. Misalnya shalat berjamaah di masjid, kajian kitab kuning bakda subuh, madrasah diniyah dan lain sebagainya. Pesantren juga memiliki tata aturan yang jelas bagi santri yang tidak mengikuti peraturan yang dibuat oleh pihak pondok pesantren dikenakan hukuman tersendiri dengan istilah takzir. ${ }^{10}$

Islam juga mengajarkan tertib dalam memanfaatkan waktu sebagaimana firman Allah dan Surah Al-Asr ayat 1-3: "Demi waktu, sesungguhnya, manusia berada dalam kerugian, kecuali orang-orang yang beriman dan mengerjakan kebajikan serta saling menasehati untuk kebenaran dan saling menasehati untuk kesabaran".

\section{Kerja keras}

Kerja keras santri banyak dimanifestasikan dalam bentuk kegiatan belajar mengajar yang berlangsung di lingkungan pesantren. Beberapa santri terutama yang mengikuti program tahfid mempunyai usaha yang keras, dimana harus menyempatkan diri dari kesibukan kuliah untuk

10 Hasil wawancara dengan pengurus pesantren putra dan putri, jam 21.30, Jumat, 23 Februari 2018 
mengejar tuntuan setoran dan kewajiban belajar (yang tidak mengikuti program tahfid). ${ }^{11}$ Beberapa santri yang ilmunya sudah pada level senior biasanya akan diamanahi pengasuh untuk mengajar ngaji santri yang junior, sehingga harapannya tidak ada rasa sungkan atau takut ketika hendak melontarkan pertanyaan atau sanggahan ketika berlangsunya proses belajar mengajar.

Beberapa santri yang sudah senior dan sudah lulus dari bidang akademik kampus biasanya disediakan lapangan pekerjaan oleh Kyai yang sekaligus pemilik yayasan. Ada beberapa yang sudah bekerja. Diantaranya menjadi guru di SMP IT Asshodiqiyah, menjadi pegawai di badan usaha milik yayasan. Dalam hal ini akan menumbuhkan etos kerja yang tinggi agar mendapatkan keberkahan dari aktivitas mondok.

Sebagaimana yang telah Allah janjikan dalam al-Qur'an Surat An-Najm ayat 39 yang berarti: "Juga bahwa seorang manusia tidak memperoleh balasan selain dari apa yang telah diusahakannya"

\section{Kreatif}

Coleman dan Hammen menyatakan bahwa berpikir kreatif merupakan cara berpikir yang menghasilkan sesuatu yang baru dalam konsep, pengertian, penemuan dan karya seni. Sukmadinata mengemukakan bahwa berpikir kreatif adalah suatu kegiatan mental untuk meningkatkan kemurnian dan ketajaman pemahaman dalam mengembangkan sesuatu. ${ }^{12}$

Pesantren juga perlu membekali dirinya dengan kemampuan dalam menciptakan karyakarya kreatif yang bisa membangun kompetensi diri sendiri maupun kompetensi masyarakat secara umum. Produk pengembangan kreativitas santri yang berada pada naungan pesantren sangat diperlukan dalam mewujudkan revolusi mental. Berpikir kritis dan kreatif dalam berkarya membangun jiwa yang kuat dan sumber daya manusia yang mandiri.

Dalam wilayah ini, gerakan santri menulis adalah sebuah gerakan yang progresif dan kreatif, karena menjadikan santri melek tentang media dan budaya literasi. Sebagaimana perkataan monumental Sayyid Quthb, "Satu perluru hanya bisa menembus satu kepala, tetapi satu tulisan bisa menembus jutaan kepala”. Era cyber menuntut santri harus mampu menaklukan media sebagai ladang dakwahal. Gerakan santri menulis sebagai gebrakan bagi santri untuk menunjukkan eksistensi diri dan kapasitas mereka dalam berdakwah di era global.

Kesiapan untuk bersaing di era global juga mendorong untuk berinovasi dalam strategi menyiapkan santri yang tidak hanya pandai berbahasa arab, namun juga mahir berbahasa inggris. Hal ini diimplemetasikan dengan adanya program diskusi bahasa inggris yang dilaksanakan seminggu sekali dan dipandu oleh santri yang kuliah di jurusan bahasa inggris. ${ }^{13}$ Dengan adanya sejumlah santri yang masih duduk di bangku SMA dan SMP, kegiatan ini membuat proses dialektika keilmuan yang sempurna dalam meningkatkan kemampuan santri yang masih berada di bangku sekolahal. Proses simbiosis mutualisme terjadi antara para santri dengan memanfaatkan latar belakang studi yang berbeda. Kegiatan tersebut sangat bermanfaat dalam

11 Hasil wawancara dengan pengurus pesantren putri, jam 21.30 WIB, 22 Februari 2018

12 Muhammad Abdul Roziq, Perwujudan Nilai-Nilai Strategis Revolusi Mental Pendidikan pada Kearifan Lokal Pesantren, Jurnal STKIP Tulungagung. hal. 29

13 Hasil wawancara dengan santri yang menjadi instruktur di pesantren putri, jam 22.30, 22 Februari 2018 
upaya menciptakan iklim intelektual yang ideal bagi para santri.

Wujud pengembangan kreatifitas santri juga terakomodir dalam kegiatan seni musik dan kaligrafi. Rebana merupakan musikyang melegenda sejak zaman dahulu dalam sejarah kebudayaan Islam, dan sampai saat ini masih dipertahankan oleh santri di Pesantren Asshodiqiyahal. Mereka membuat variasi baru supaya lebih memperindah alunan musik rebana yang telah ada. Begitu juga dalam bidang Kaligrafi, para santri dibekali dengan pelatihan Kaligrafi. Kebetulan juga ada santri yang mahir dalam bidang ini, sehingga bisa menularkan kemampuannya kepada sesama santri yang lain. Bahkan dalam bidang Kaligrafi ini selain bisa sebagai ajang mengasah kreativitas juga bisa mendatangkan manfaat dari segi ekonomi. Kegiatan tersebut dilaksanakan untuk menumbuhkan jiwa keratif dalam diri santri sehingga diharapkan santri tidak hanya ahli dalam bidang agama, namun juga dalam bidang kesenian.

\section{Mandiri}

Kemandirian adalah hasrat untuk mengerjakan sesuatu bagi diri sendiri yang diwujudkan dalam bentuk kreativitas dan kemampuan mencipta. ${ }^{14}$ Dalam kebijakan pembangunan Nasional Pembangunan Karakter Bangsa tahun 2010-2025, Kemandirian bangsa menjadi salah satu permasalahan bangsa ini. Hingga saat ini tingkat ketergantungan bangsa Indonesia terhadap asing masih cukup tinggi.

Dalam realitas yang ada di pesantren As-Shodiqiyah, keuangan pondok diambilkan dari hasil bulanan santri. Sedangkan untuk pembangunan dibiayai oleh pemilik yayasan sendiri tanpa mencari sumbangan, namun jika ada pihak yang ingin berkontribusi dalam pembangunan, pengasuh tidak akan menolaknya.

Berkaitan dengan kebiasan santri yang bersifat rutinitas menunjukkan kecenderungan santri lebih mampu dan berani dalam mengambil dan melaksanakan keputusan secara mandiri, misalnya pengelolaan keuangan, perencanaan belanja, perencanaan aktivitas rutin, dan sebagainya. Hal ini tidak lepas dari kehidupan mereka yang tidak tinggal bersama orangtua mereka dan tuntutan pesantren yang menginginkan santri-santri dapat hidup dengan berdikari. Santri dapat saling tuar pengalaman kehidupan dengan teman-teman santri lainnya yang mayoritas seusia (sebaya) yang pada dasarnya memiliki kecenderungan yang sama. Apabila kemandirian tingkah-laku dikaitkan dengan rutinitas santri, maka kemungkinan santri memiliki tingkat kemandirian yang tinggi.

\section{Demokratis}

Menurut Kemendiknas, demokratis adalah sikap dan cara berpikir yang mencerminkan persamaan hak dan kewajiban secara adil dan merata antara dirinya dengan orang lain. Sedangkan dalam KBBI, demokratis adalah yang bersifat demokrasi; berciri demokrasi.

Demokrasi adalah konsep jati diri dan esensi karakter bangsa. ${ }^{15}$ Dalam Kebijakan Nasional Pembangunan Karakter Bangsa tahun 2010-2025, demokrasi adalah konsep jati diri dan esensi

14 Rofik, dkk, Pemberdayaan Pesantren, (Yogyakarta: LKiS, 2005). hal. 61

15 Dalam Kebijakan Nasional Pembangunan Karakter Bangsa tahun 2010-2025, Pemerintah Repubik Indonesia 2013. h. 21 
karakter bangsa. Dalam implementasi di dalam kehidupan pesantren, demokrasi diwujudkan dalam proses pemilihan lurah atau pimpinan pondok. Regulasinya menggunakan konsep seperti yang diajarkan oleh para khulafaur rasyidin pada masa dahulu. Mekanisme pemilihan pertama adalah musyawarah oleh dewan ahlul hal wal 'aqdi untuk menentukan siapa bakal calon yang sesuai dengan kriteria pemimpin. Setelah didapatkan 5 bakal calon, lalu disowankan ke ndalem pengasuh untuk difilter kembali. Sehingga mengerucut menjadi dua calon. Dan pada fase terakhir adalah pemilihan umum yang dilaksanakan oleh para santri ${ }^{16}$.

Mekanisme di atas telah menggunakan konsep yang diajarkan oleh khulafaurrosyidin dan dikonsolidasikan dengan praktek demokrasi di Indonesia. Tentu demikian adalah operasionalisasi yang ideal untuk menumbuhkan nilai-nilai pancasila yang termaktub di dalam Pancasil sila ke 4 yaitu: "Kerakyatan yang dipimpin oleh hikmat kebijaksanaan dalam permusyawaratan perwakilan".

\section{Rasa ingin tahu}

Kemendiknas mendefinisikan rasa ingin tahu sebagai cara berpikir, sikap, dan perilaku yang mencerminkan penasaran dan keingintahuan terhadap segala hal yang dilihat, didengar, dan dipelajari secara lebih mendalam.

Dalam prakteknya diskusi di kelas ulya di lingkungan pesantren lebih menarik perhatian dan rasa ingin tahu santri tentang permasalahan yang sedang didiskusikan. Dialog interaktif akan terjadi ketika santri mulai bertanya dan berpendapat terkait suatu obyek kajian. Rasa ingin tahu santri mencerminkan bahwa level pengetahuan akan mendorong santri untuk terus bertanya dan bertanya.

\section{Semangat kebangsaan atau nasionalisme}

Semangat kebangsaan atau nasionalisme, yakni sikap dan tindakan yang menempatkan kepentingan bangsa dan negara di atas kepentingan pribadi atau individu dan golongan. Semangat nasionalisme adalah ruh dari persatuan yang mewujudkan kehidupan sejahtera, ini pula yang ditekankan oleh para Kyai yang dulu telah memperjuangkan kemerdekaan Negara Kesatuan Republik Indonesia. Nasionalisme adalah pembangunan mentalitas, bukan pada segi materiil dan mengejar kemajuan saja. Semua itu harus diimbangi dengan moralitas Islam yang menjadi nafas kehidupan muslim di Indonesia. ${ }^{17}$

Upacara hari santri, sumpah pemuda adalah sampel yang bisa dijumpai di pesantren Asshodiqiyahal. Hampir setiap ada peringatan hari kebangsaan yang sakral selalu ikut menghormati dengan melaksanakan upacara. Demikian untuk memupuk kecintaan terhadap bangsa dan tanah air mereka. ${ }^{18}$

\section{Cinta tanah air}

Cinta tanah air, yakni sikap dan perilaku yang mencerminkan rasa bangga, setia, peduli, dan

16 Hasil wawancara dengan pengurus pesantren putri, jam 21.30 WIB, 22 Februari 2018

17 Zamakhsari Dzofier, Tradisi Pesantren, (Jakarta: LP3ES, 2011). hal. 275

18 Muhammad Abdul Roziq, Perwujudan Nilai-Nilai Strategis Revolusi Mental Pendidikan pada Kearifan Lokal Pesantren, Jurnal STKIP Tulungagung. hal. 29 
penghargaan yang tinggi terhadap bahasa, budaya, ekomoni, politik, dan sebagainya, sehingga tidak mudah menerima tawaran bangsa lain yang dapat merugikan bangsa sendiri. Adagium hubbul wathan minal iman menjadi slogan yang sangat dijiwai betul oleh para santri. Dengan mempelajari semangat yang diwariskan oleh para ulama dan santri yang dahulu berjuang mempertahankan keutuhan NKRI dan rela berkorban melawan penjajahal.

Hal ini dibuktikan dengan adanya upacara-upacara pada hari besar nasional seperti Upacara HUT RI, hari santri nasional, hari sumpah pemuda. Sehingga harapannya semangat perjuangan tetap mengalir di dalam hati-sanubari santri pesantren. Karena tidak bisa dipungkiri bahwa para founding father bangsa Indonesia mayoritas adalah para ulama.

\section{Menghargai prestasi}

Menurut Kemendiknas Menghargai prestasi, yakni sikap terbuka terhadap prestasi orang lain dan mengakui kekurangan diri sendiri tanpa mengurangi semangat berprestasi yang lebih tinggi. Komunikasi adalah sebuah proses interaksi untuk berhubungan dari pihak satu ke pihak yang lainnya, ini berupa ide-ide abstrak dan gagasan untuk mencari atau menyimpulkan data yang dikemas secara langsung atau tidak langsung, dengan visual, kode suara, atau kode tulisan. ${ }^{19}$

Sertifikat wisuda diniyah, khatmil quran binnadhor dan bilghoib, pemberian penghargaan berupa buku atau kitab bagi santri yang berhasil mendapatkan peringkat 1-3 pada level diniyah, merupakan berbagai bentuk penghargaan yang diterapkan oleh Pondok Pesantren AsShodiqiyah bagi para santri yang berhasil mendapatkan prestasi dalam kegiatan belajar mengajar di pesantren. Hal tersebut dilakukan sebagai sarana motivasi bagi para santri untuk senantiasa meningkatkan prestasi mereka dalam mengaji di Pondok Pesantren. ${ }^{20}$

\section{Komunikatif}

Menurut KBBI, komunikatif adalah keadaan saling dapat berhubungan (mudah dihubungi); mudah dipahami (dimengerti). Menurut Kemendiknas Komunikatif beramakna senang bersahabat atau proaktif, yakni sikap dan tindakan terbuka terhadap orang lain melalui komunikasi yang santun sehingga tercipta kerja sama secara kolaboratif dengan baik.

Metode komunikatif juga telah diterapkan dalam proses mengaji. Waktu Tanya jawab antara seorang guru ngaji dengan seorang santri merupakan metode komunikatif di dalam pesantren. ${ }^{21}$ Warga yang syukuran atau peringatan kamatian hari tertentu, mengundang santri, sehingga kegiatan ini mengajarkan tenggang rasa sekaligus wahana bersosialisasi dengan masyarakat sekitar. $^{22}$

\section{Cinta damai}

Menurut Kemendiknas Cinta damai adalah sikap dan perilaku yang mencerminkan suasana damai, aman, tenang, dan nyaman atas kehadiran dirinya dalam komunitas atau masyarakat tertentu.

19 Rofik, dkk, Pemberdayaan Pesantren, (Yogyakarta: LKiS, 2005). Hal. 59

20 Hasil wawancara dengan pengurus pesantren putri, jam 21.30 WIB, 22 Februari 2018

21 Zamakhsari Dzofier, Tradisi Pesantren, (Jakarta: LP3ES, 2011). Hal. 57

22 Hasil wawancara dengan pengurus pesantren putri, jam 21.30 WIB, 22 Februari 2018 
Para santri adalah penerus perjuangan Nabi, sehingga dalam berjuang pun harus meneladani akhlak-akhlak yang telah dicontohkan oleh Nabi. Misal Nabi tidak pernah mencaci jika dicaci, tidak pernah membalas kejahatan dengan kejahatan, tetapi selalu menebar dakwah dengan sikap yang lembut, cinta damai dan penuh kasih sayang. Santri pun harus berakhlak demikan, dimanapun menebar cinta kasih dan kedamaian. Karena Islam adalah rahmat untuk seluruh alam.

\section{Gemar membaca}

Menurut Kemendiknas, gemar membaca adalah kebiasaan dengan tanpa paksaan untuk menyediakan waktu secara khusus guna membaca berbagai infomasi, baik buku, jurnal, majalah, koran, dan sebagainya, sehingga menimbulkan kebijakan bagi dirinya.

Dari seluruh santri, sebagian ada yang sangat gemar membaca, bahkan ada yang mempunyai buku yang ditempatkan di tiga lemari besar karena banyaknya buku yang dibaca dan dikoleksinya. Tidak hanya membaca buku mata kuliah saja, namun juga banyak yang sangat hobi mengkaji kitab-kitab klasik karya ulama-ulama yang memang setiap harinya menjadi nutrisi untuk akal yang haus akan ilmu agama. Santri bercita-cita menjadi orang bermanfaat, mengembangkan keahliannya mulai dari menguasai bahasa arab terlebih dahulu yang dibimbing oleh guru ngaji yang mengajar dengan sistem sorogan, ${ }^{23}$ sehingga mau tidak mau santri harus senantiasa membaca.

Kegemaran membaca adalah sebuah kesadaran yang bersumber dari wahyu Allah yang diwahyukan pertama kali kepada Nabi Muhammad SAW, yaitu surat Al-Alaq ayat 1:

"Bacalah dengan menyebut nama Rabbmu yang menciptakan semua makbluk"

Membaca bukan hanya semata keinginan dan hasrat yang timbul dari dalam diri seorang yang haus ilmu, namun juga tuntunan agama.

\section{Peduli lingkungan}

Dalam pandangan Kemendiknas Peduli lingkungan ditafsirkan sebagai sikap dan tindakan yang selalu berupaya menjaga dan melestarikan lingkungan sekitar. Santri tidak hanya mengutamakan hablun minallah tetapi juga hablun minal 'alam.

Nilai keteladanan yang diajarkan para santri mengenai sikap peduli sosial yakni tampak pada kehidupannya sewaktu di pondok pesantren. Mereka melakukan kegiatan kerja bakti atau popular disebut roan. Sikap peduli lingkungan sangat dijiwai oleh para santri sesuai dengan penjelasan Allah yang artinya:

"Dan janganlah kamu membuat kerusakan di muka bumi, sesudah (Allah) memperbaikinya dan berdoalah kepada-Nya dengan rasa takut (tidak akan diterima) dan harapan (akan dikabulkan). Sesungguhnya rahmat Allah amat dekat kepada orangorang yang berbuat baik". (QS.Al-A'raf:56)

\section{Peduli sosial}

Menurut Kemendiknas, peduli sosial, adalah sikap dan perbuatan yang mencerminkan 
kepedulian terhadap orang lain maupun masyarakat yang membutuhkannya. Merajut hubungan dengan melalui kepedulian sosial akan menciptakan budaya yang kondusif dalam rangka pengabdian masyarakat. Jika dihitung matematis-ekonomis, pesantren dan masyarakat pedesaan adalah sebuah lingkaran strategis dalam upaya pembangunan masyarakat. Dan pesantren sebenarnya mengandung potensi ekonomi cukup besar, dan apabila mampu dioptimalkan tentu akan bermanfaat untuk masyarakat sekitarnya. ${ }^{24}$

Dalam hal ini pengurus pesantren mempunyai kebiasaan bertakziyah ke keluarga santri yang meninggal, atau santri yang sakit biasanya dijenguk oleh teman-temannya. Ini merupakan proses replika sosialisasi yang kelak akan santri rasakan dalam kehidupan di masyarakat. Dengan kondisi masyarakat yang rata-rata berekonomi menengah ke bawah sehingga perlu meningkatkan potensi pesantren dalam upaya mengentas dan membantu kehidupan masyarakat sekitarnya. ${ }^{25}$

Qurban adalah salah satu program rutin tahunan yang mengejawantahkan nilai-nilai kepedulian sosial. Salah satu amal yang utama di dalam Islam adalah memberi makan kepada pada fakir miskin dan tetangga. Melalui qurban yang tiap tahunnya selalu dilaksanakan dilingkungan pesantren akan menyambung tali ikatan antara santri dengan masyarakat sekitar. Masyarakat berduyun-duyun antre untuk mendapatkan daging, dan santri di sini sebagai pengatur pembagian daging qurban. Sambil menyelam minum air, adalah istilah yang sesuai untuk mengambarkan proses dialog sosial antara santri dengan masyarakat. ${ }^{26}$

\section{Tanggung jawab}

Definisi tanggung jawab menurut Kemendiknas adalah sikap dan perilaku konsisten seorang dalam melakukan tugas dan kewajibannya, baik yang berikatan dengan diri sendiri, sosial, masyarakat, bangsa, negara, maupun agama. Contoh sikap tanggung jawab para santri dan belajar untuk melaksanakan kewajiban pribadinya atas segala kegiatan yang telah dijadwalkan. Atau santri yang menjadi pengurus pesantren bertanggung jawab terhadap pengasuh pesantren. ${ }^{27}$

\section{G. Penutup}

Pesantren merupakan termpat penanaman karakter yang sangat efektif. Dalam hal ini pesantren menjadi sangat memiliki posisi strategis dalam pembentukan karakter bangsa. Dalam realitasnya ternyata pesantren berhasil bersinergi dengan kebijakan pemerintah dalam ranah penanaman karakter melalui serangkaian desain kegiatan yang menjadi rutinitas para santrinya.

Diantara nilai-nilai karakter yang dibangun di Pondok Pesantren Asshodiqiyah yang notabennya kebanyakan santrinya merupakan mahasiswa, adalah sebagai berikut : nilai religius, jujur, toleransi, disiplin, kerja keras, kreatif, mandiri, demokratis, rasa ingin tahu, semangat kebangsaan atau nasionalisme, cinta tanah air, menghargai prestasi, komunikatif, cinta damai, gemar membaca, peduli lingkungan, peduli sosial, tanggung jawab.

24 Rofik, dkk, Pemberdayaan Pesantren, (Yogyakarta: LKiS, 2005). hal. 15

25 Hasil wawancara dengan pengurus pesantren putr, jam 21.30 WIB, 23 Februari 2018

26 Rofik, dkk, Pemberdayaan Pesantren, (Yogyakarta: LKiS, 2005). hal. 15

27 Ibid,. hal. 16 
Oleh sebab itulah hendaknya pihak pesantren senantiasa memperkuat eksistensinya dalam rangka menanamkan karakter bagi generasi muda. Sehingga diharapkan masyarakat Indonesia akan menjadi bangsa yang besar.

\section{Bibliografi}

Al Qur’anul Karim dan Terjemahannya. 2004. Kementerian Agama RI.

Departemen Pendidikan dan Kebudayaan, 1997, Kamus Besar Bahasa Indonesia, Balai Pustaka, Jakarta

Dewantara, Ki Hadjar, 2009, Menuju Manusia Merdeka, Leutika, Yogyakarta

Dzofier, Zamakhsari, 2011, Tradisi Pesantren, LP3ES, Jakarta

Hamid, A. Y, 2009, Bunga Rampai Asuhan Keperawatan Jiwa. Penerbit Buku Kedokteran EGC, Jakarta

Kemendiknas. 2011. Panduan Pelaksanaan Pendidikan Karakter. Jakarta: Badan Penelitian dan Pengembangan. Pusat Kurikulum dan Pembukuan

Kemendiknas. 2013. Strategi Pembelajaran Pendidikan Karakter. Jakarta: Kementrian dan Dinas Nasional

Moloeng, Lexy J. 2002. Metodologi penelitian kualitatif, PT Remaja Rosda Karya, Bandung

Nashir, Haedar, 2013, Pendidikan Karakter Berbasis Agama \& Budaya, Multi Presindo, Yogyakarta

Nasution, S. 1992. Metode Penelitian Naturalistik Kualitatif, Tarsito, Bandung

Rofik, dkk, 2005, Pemberdayaan Pesantren, LKiS, Yogyakarta

Roziq, Muhammad Abdul, Perwujudan Nilai-Nilai Strategis Revolusi Mental Pendidikan pada Kearifan Lokal Pesantren, Jurnal STKIP Tulungagung

Sudewo, Erie, 2011, Character Building: Menuju Indonesia Lebih Baik, Repubika Penerbit, Jakarta

Wawancara dengan pengurus pesantren putra (PP Asshodiqiyah), Ahad 23 Februari 2018

Wawancara dengan pengurus pesantren putri (PP Asshodiqiyah), 22 Februari 2018

www.http://nasional.kompas.com, diakses 19 Februari 2018, pukul 21.45 wib 